University of Maryland Francis King Carey School of Law

DigitalCommons@UM Carey Law

3-21-1997

\title{
Genetic Information and the Workplace: Legislative Approaches and Policy Challenges
}

\author{
Karen $\mathrm{H}$. Rothenberg \\ University of Maryland School of Law, krothenberg@law.umaryland.edu \\ Barbara Fuller \\ Mark Rothstein \\ Troy Duster \\ Mary Jo Ellis Kahn
}

See next page for additional authors

Follow this and additional works at: https://digitalcommons.law.umaryland.edu/fac_pubs

Part of the Genetics Commons, and the Health Law and Policy Commons

\section{Digital Commons Citation}

Rothenberg, Karen H.; Fuller, Barbara; Rothstein, Mark; Duster, Troy; Ellis Kahn, Mary Jo; Cunningham, Rita; Fine, Beth; Hudson, Kathy; King, Mary-Claire; Murphy, Patricia; Swergold, Gary; and Collins, Francis, "Genetic Information and the Workplace: Legislative Approaches and Policy Challenges" (1997). Faculty Scholarship. 176.

https://digitalcommons.law.umaryland.edu/fac_pubs/176

This Article is brought to you for free and open access by the Francis King Carey School of Law Faculty at DigitalCommons@UM Carey Law. It has been accepted for inclusion in Faculty Scholarship by an authorized administrator of DigitalCommons@UM Carey Law. For more information, please contact smccarty@law.umaryland.edu. 


\section{Authors}

Karen H. Rothenberg, Barbara Fuller, Mark Rothstein, Troy Duster, Mary Jo Ellis Kahn, Rita Cunningham, Beth Fine, Kathy Hudson, Mary-Claire King, Patricia Murphy, Gary Swergold, and Francis Collins 


\section{Genetic Information and the Workplace: Legislative Approaches and Policy Challenges}

Karen Rothenberg, ${ }^{\star}$ Barbara Fuller, Mark Rothstein, Troy Duster, Mary Jo Ellis Kahn, Rita Cunningham, Beth Fine, Kathy Hudson, Mary-Claire King, Patricia Murphy, Gary Swergold, and Francis Collins 


\title{
Genetic Information and the Workplace: Legislative Approaches and Policy Challenges
}

\author{
Karen Rothenberg, ${ }^{\star}$ Barbara Fuller, Mark Rothstein, \\ Troy Duster, Mary Jo Ellis Kahn, Rita Cunningham, Beth Fine, \\ Kathy Hudson, Mary-Claire King, Patricia Murphy, \\ Gary Swergold, Francis Collins
}

"In the employment setting, discrimination among individuals has long been legally, ethically, and socially acceptable" (1). Employers may select prospective employees on the basis of their past experience or their education but are prohibited from selecting emplovees on the basis of specific categories such as age, color, and ethnic origin (1). Now there are numerous reasons for employers to expand the selection process to include genetic information. Employers are increasingly concemed about the spiraling cost of health insurance as well as the possibility of genetic susceptibility to illness caused by exposure to workplace toxins (2).

The use of genetic information in the workplace poses societal risks that have an impact on employment possibilities, health insurance, and privacy. Individuals who might otherwise believe that they can benefit from genetic testing may decline it be-

The authors are memcers of the Committee on Genetic Information and the Workplace of the National Action Plan on Breast Cancer NAPBC) and the National Institutes of Health-Department of Energy Working Group on Ethical, Legal and Social Impilications of Human Genome Research ithe ELSI Working Groupl. K. Rothenberg is director of the Law and Heaith Care Program, University of Maryland School of Law, and chair of the Committee on Genetic Information and the Workplace and is a member of the NAPBC. B. Fuller is with the NAPBC. M. Rothstein is at the Heaith Law and Policy institute, University of Houston Law Center, and a member of the NAPBC. T. Duster is at the institute for the Study of Social Change, University of California. Berkeley, and is chair of the ELSI Working Group. M. J. Elis Kahn is with the Virginia Breast Cancer Foundation and is Co-chair of the NAPBC Hereditary Susceptibility Working Group. R. Cunningham is with the African American Breast Cancer Allance of Minnesota and is a member of the NAPBC. B. Fine is at Northwestern University Medical School and is a member of the ELSI Working Group. K. Hudson is at the National Human Genome Research Institute. National institutes of Health. M.-C. King is with the Division of Medical Genet ics, University of Washington, and is a member of the NAPBC. P. Murphy is with OncorMed, Gaithersburg, $\mathrm{MD}$, and is a member of the NAPBC. G. Swergold is at the Center for Biologics Evaluation and Research, U.S. Food and Drug Administration, and is a member of the NAPBC. F. Collins is at the National Human Genome Research Institute, National institutes of Heaith, and is co-chair of the NAPBC Hereditary Susceptibility Working Group.

* To whom correspondence should be addressed at the Law and Health Care Program, University of Maryland School of Law, 500 West Baitimore Street, Baltimore, MD 21201, USA cause of their fear of employment discrimination and lack of privacy in the workplace (3). As a consequence, the future of research on the benefits and risks of predictive genetic testing may also be compromised (4). Thus, policy-makers need to evaluate legislative and regulatory strategies to address these concerns.

The Hereditary Susceptibility Working Group of the National Action Plan on Breast Cancer (NAPBC), coordinated by the PHS Office on Women's Health (5), recently joined with the National Institutes of Health-Department of Energy (NIHDOE) Working Group on Ethical, Legal and Social Implications of Human Genome Research (the ELSI Working Group) (6) to address the issue of genetic information in the workplace. This commitment builds on their combined efforts to first address the use of, misuse of, and access to genetic information in the health insurance context, and then to focus on these concerns in the workplace. Obviously, the fears of discrimination in health insurance and employment are intertwined. Wirhout a job, most people in our country do not have health insurance. Yet genetic information in the workplace poses unique challenges. Employers in most jurisdictions are not prohibited from requiring genetic testing, even though there is insufficient evidence to justify the use of any existing test for genetic susceptibility as a basis for employment decisions. Even if employers do not use genetic testing, they still may have access to the medical records of their employees and prospective employees, and thus will be able to find out if these individuals have certain predispositions to disease. Employers may be reluctant to hire or promote individuals they believe will become prematurely unable to work (2). Thus, legislative and regulatory strategies to address discrimination and privacy concerns in the workplace should be considered along with the NAPBC and ELSI Working Group recommendations on genetic information and health insurance that were promulgated and disseminated in $1995(7,8)$.
Evolution of State Legislation

The first law addressing genetic discrimination in the workplace was enacted in 1975 when North Carolina passed legislation prohibiting employers from discriminating against any person possessing the traits for sickle cell or hemoglobin $C(9)$. Over the next decade, four other states passed laws prohibiting employment discrimination based on the sickle cell trait, other specified traits, and carrier status (10). In 1989, Oregon added "genetic screening" to an existing law that made it unlawful for an employer to subject an employee or prospective employee to different types of tests, including breathalyzers and polygraphs (11). Although this law did not include a definition for genetic screening, it was the first state law to go beyond specific traits and disorders.

More comprehensive legislation emerged in 1991, when Wisconsin prohibited workplace discrimination, prohibited employer access to genetic test results, and provided privacy protections for employees (12). This legislation addressed not only employers but also labor organizations, employment agencies, and licensing agencies. The focus of the legislation was on genetic testing and not on the use of genetic information derived from phenotype indicators and family history. This Wisconsin legislation provides for genetic testing of an employee if the employee requests the test. The law also requires written and informed consent and specifies that no adverse action may be taken against the employee as a result of the test. This employee testing may only be conducted for the purpose of investigating a workers' compensation claim or to determine the employee's susceptibility or level of exposure to toxic chemicals in the workplace. Wisconsin's criminal code specifically makes it unlawful to disclose genetic test information without the written and informed consent of the individual (13).

Thus, the Wisconsin approach attempts to integrate protection against discrimination in employment with some privacy protection. Similar approaches have been incorporated to varying degrees in recent legislation passed in lowa (14), Rhode Island (15), New Hampshire (16), New York (17), and Oregon (18). This trend parallels similar state initiatives in the health insurance context $(7,8)$.

In 1996, New Jersey enacted comprehensive legislation that prohibits employment discrimination based on genetic information (19). Thus, New Jersey does not focus on genetic testing alone but expands the prohibition to include discrimination on the basis of "information about genes, gene products or inherited characteristics 
that may derive from an individual or family member" $(19,20)$. New Jersey also prohibits retaliation by employers if an employee or prospective employee refuses to take a generic test or reveal the results of a genetic test (19).

In contrast. New York law specifies that the employer may ". . . require a specified genetic test as a condition of employment where such a test is shown to be directly related to the occupational environment, such that the employee or applicant with a particular genetic anomaly might be at an increased risk of disease as a result of working in said environment," but it is silent on the need for the written and informed consent of the emplovee or applicant (17). Even when state laws require informed consent before genetic testing, they do not address whether the informed consent process will provide notice that the test results may be disclosed without authorization under certain circumstances, including paternity, criminal proceedings, or health department protocols.

\section{Recent Federal Initiatives}

In 1995, the Equal Employment Opportunity Commission (EEOC) issued a guidance in its compliance manual on the definition of "disability" that addresses genetic discrimination in the workplace. It stated that the Americans with Disabilities Act (ADA) would protect individuals subjected to discrimination on the "basis of genetic information relating to illness, disease or other disorders" (21). To further clarify its position, it cires as an example an individual with a positive predictive genetic test for colon cancer as being subject to protection under the ADA if the employer "regards" the individual as having a disability and has discriminated against the individual because of this perception. However, it is not clear whether this coverage will extend to unaffected individuals who are carriers of recessive or $\mathrm{X}$-linked mutations. To date, there have been no genetic discrimination complaints filed with the EEOC, and the guidance has yet to be tested in court. Thus, in the absence of judicial decisions, the amount of protection actually provided by the ADA remains limited.

Even though the ADA potentially offers protection from discrimination, the focus of the ADA is not the protection of an employee's privacy (22). Although the ADA does prevent employers from making preemployment medical inquiries, it does not prevent employers from obtaining medical information, including genetic information, after a conditional offer of employment. Employers can require a preplacement medical exam, which may include a physical examination and blood tests (including genetic tests). They may also require a general medical release of an individual's medical records. Although an employer is prohibited from discriminating on the basis of a disability, it is difficult for the individual to prove that he or she did not get a job or promotion, for example, because of disability or other genetic information (1).

In 1996, Congress passed the Health Insurance Portability and Accountability Act (23), which primarily applies to employer-based health insurance coverage and was designed to allow workers to maintain insurance coverage if they change or leave their jobs. It pertains to employers who provide health insurance coverage through self-funded plans as well as through insurance companies, thus including those selffunded plans that have been beyond the reach of state legislation because of the Employee Retirement Income Security Act (ERISA) preemption (24).

The law specifically prohibits a group health insurance plan from using "genetic information" to establish rules for eligibility or continued eligibility. It also provides that genetic information shall not be treated as a "preexisting condition in the absence of the diagnosis of the condition related to such information" (23). However, the law does not provide any privacy protections. The burden would be on the employee to prove that the insurer did not use genetic information to deny coverage or affect the terms and conditions of health coverage. Furthermore. it does not prohibit group health plans from increasing rates, excluding all coverage for a particular condition, or imposing lifetime caps on benefits as long as plan characteristics are not "directed at individual sick employees or dependents" $(23,25)$.

\section{Policy Implications}

The development of public policy to address genetic information in the workplace must be analyzed in light of the uncertainty about the future scope and impact of genetic testing and the realities of the political process. It also must be placed in context with state and federal disability laws and other genetic discrimination and privacy legislation.

The primary legislative approach to addressing genetic information in the workplace is prohibition of employment discrimination. Although some state laws prohibit employers from using the results of a chemical test of DNA or the protein product of a gene, most of the laws do not expressly prohibit employers from using phenotype indicators, patterns of inheritance of genetic characteristics, or requests for genetic test- ing as a basis for discrimination. Although some laws do attempt to prohibit both access to and use of genenc test results, others provide for use of test results if the information is job-related. At the present time, however, there is no scientific evidence to link unexpressed genetic factors and the ability to perform a job function. Therefore, employers cannot prove that the use of genetic information is "job-related and consistent with business necessity," the standard often applied in federal and state antidiscrimination laws (26). Furthermore, some state laws provide for generic testing by employers in order to determine an employee's susceptibility to toxic chemicals or substances in the workplace, even though cleaning up the environment would enhance the working conditions for all employees and would alleviate the need for genetic testing of individual employees (28).

On the federal level, the ADA and the Health Insurance Portability and Accountability Act of 1996 appear to offer limited protection from discrimination but do not prohibit employers and insurers from gaining access to genetic information. At present, there is no uniform protection against the use of, misuse of, and access to genetic information in the workplace.

With these policy considerations in mind, the Hereditary Susceptibility Working Group of the NAPBC and the ELSI Working Group developed the following recommendations for state and federal policy-makers $(26,27)$.

1) Employment organizations should be prohibited from using genetic information to affect the hiring of an individual or to affect the terms, conditions, privileges, benefits, or termination of employment unless the employment organization can prove that this information is job related and consistent with business necessity.

2) Employment organizations should be prohibited from requesting or requiring collection or disclosure of genetic information prior to a conditional offer of employment, and under all other circumstances, employment organizations should be prohibited from requesting or requiring collection or disclosure of genetic information unless the employment organization can prove this information is job related and consistent with business necessity, or otherwise mandated by law. Written and informed consent should be required for each request, collection or disclosure.

3) Employment organizations should be restricted from access to genetic information contained in medical records released by individuals as a condition of employment, in claims filed for reimbursement of health care costs, and other sources.

4) Employment organizations should be 
prohibited from releasing genetic information without prior written authorization of the individual. Written authorization should be required for each disclosure and include to whom the disclosure will be made.

5) Violators of these provisions should be subject to strong enforcement mechanisms, including a private right of action.

It is hoped that these recommendations will stimulate a comprehensive approach to addressing genetic privacy and discrimination in the workplace.

\section{REFERENCES AND NOTES}

1. M. A. Rcinstein. Houston Law Rev. 29, 25 (1992).

2. Councit on Ethical and Judicial Affairs, American Medical Association, J. Am. Med. Assoc. 266, 1827 (1991).

3. C. Lerran et al. ibid. 275, 1885 (1996); E. V. Lapham et al., Science 274, 621 (†996).

4. G. Kolata New York Times, 4 February 1997, p. C1.

5. Members of the NAPBC Working Group: Barbara Brenner. Kathilen Calzone, Francis Collins, Ellen Crowiey. Rita Cunningham, Sherman Elias, Judy Garber. Ruthann Giusti, Jay Harris, Joseph Hurd, Mary Jo Elis Kann, Mary-Claire King, Caryn Lerman, Mary Jare Massie. Paul McDonough, Patricia Murphy, Barcara Rimer, Karen Rothenberg, Mark Rothstein, Karen Steinberg, Jill Stopfer, and Gary Swergold. The NAPBC, condinated by the U.S. Public Health Service's (PHS's) Office on Women's Health, is a pucic-private partnership designed to stimulate rapid progress in eradicating breast cancer and has identified genetic discrimination and privacy issues as high priorities.

6. Members of the ELSI Working Group: Betsy Anderson, James Bowman (dissenting). David Cox, Troy Duster, Rebecca Eisenberg, Beth Fine, Neil Holtz man, Philip Kitcher, Joseoh Mcinerney, John Mulvihill, Jeffrey Murray, Dorothy Nelkin, Rayna Rapp, and Marsha Saxton. The NIH-DOE ELSI Working Group has a "broad and diverse membership including genome scientists: medical geneticists; experts in law, ethics, and philosophy; and consumers, to explore and propose options for the development of sound professional and public policies related to human genome research and its applications" $(7)$.

7. K. L. Hudson, K. H. Rothenberg, L B. Andrews, M J. Ellis Kahn, F. S. Collins, Science 270, 391 (1995)

8. K. Rothenberg, J. Law Med. Ethics 23, 312 (1995).

9. North Carolina, NC ST: 95-28.1 (1975).

10. Florida, FL ST: 48.075 (1978); Louisiana, LA ST: 23:1001 (1982); New Jersey, NJ ST: 10:5-12 (1981); and New York, NY ST: 48-a (1990)

11. Oregon, OR ST: 659.227 (1989).

12. Wisconsin, WI ST: 111.32, 111.372, 111.375 111.39, and 942.07 (1991).

13. Wisconsin, WI ST: 942.07 (1991).

14. Iowa, IA ST: 729.6 (1992)

15. Rhode Island, RI ST: $28-6.7-1$ and $28-6.7-3$ (1992)

16. New Hampshire, NH ST: $141-\mathrm{H}: 1$ and $141-\mathrm{H}: 3$ (1995).

17. New York, NY A: 7839 (1996).

18. Oregon, OR ST: $659.036,659.227,659.700$, and 659.705 (1995).

19. New Jersey, NJ ST: 695 (1996).

20. This definition was jointly developed by the NAPBC and the NIH-DOE ELSI Working Group (7).

21. Equal Employment Opportunity Commission, Compliance Manual, vol. 2, Section 902 . Order 915.002 , $902-45$ (1995).
22. M. Rothstein, presentation given at the Workshop on Genetic information and the Workplace: Implications for Employment, Insurance and Privacy, Bethesda, MD, 4 October 1996.

23. Health Insurance and Portability and Accountability Act, 104 Public Law No. 104-191, 701,110 STAT, 1936 (1996)

24. 29 U.S. Code (1974)

25. H.R. Rep. No. 104-736 @ 406-07 (1996).

26. The NAPBC and the NIH-DOE ELSI Working Group, "Recommendations on Genetic Information and the Workplace" (1997). For a complete copy of the recommendations, contact the NAPBC, U.S. Public Health Service's Office on Women's Health, H. H. Humphrey Building, Room 718F, 200 Independence Avenue. SW, Washington, DC 20201. USA. Telephone: 202-401-9587. URL: http://www. napbc.org

27. The recommendations include the following deninitions: "Employment organizations" include, but are not limited to, employers, labor organizations, employment agencies, and licensing agencies. "Genetic information" is information about genes, gene products, or inherited characteristics that may derive from the individual or a family member.

28. lowa, IA ST: 729.6 (1992); New York, NY A: 7839 (1996); Wisconsin, WI ST: 111.372 (1991).

29. The authors wish to thank all the individuals who participated in the Workshop on Genetic information and the Workplace: Implications for Employment Insurance and Privacy for their insights, questions, and suggestions, and wish to recognize Henry Greely, Andrew imparato, Anne Rufo Pheips, Bobby Silverstein, Elizabeth Thomson, and Joan Weiss for their additional assistance. The views expressed here are those of the authors and do not necessarily represent federal govemment policy. 